\title{
An Artistic Analysis on Robert Frost's Desert Places
}

\author{
Li Wang \\ School of Foreign Languages, Qingdao University of Science and Technology, Qingdao, China
}

\begin{abstract}
Desert Places is one of Frost's dark poems that show the poet's deep thought about life philosophy and helplessness towards reality. This article analyzes this dark poem from the perspective of elements to show that how these elements work together to reinforce the theme of the poem in order to help readers to have a better understanding about this poem as well as the artistic techniques the author employed to elaborate the life wisdom through image and common settings. The elements include title, setting, imagery, syntax, sound quality, rhyme scheme, rhythm, figures of speech, diction and tone.
\end{abstract}

Index Terms-dark, elements, theme

\section{INTRODUCTION}

As Huang (2000) argues that Robert Frost is a symbolist, a realist, a philosopher, a moralizer, a lyricist, a farmer-poet, and emblemist, he is a shining superstar in American literature and is also considered one of the greatest modern poets and meanwhile the most controversial one. He occupies an important position not only in American literature, but also in world literature. Most of his poems are about New England country life, expatiating the inharmonious relationship between man and nature, and between man and man.

To the American public, like Trinkha (1990) thinks that Frost is one of the notable craftsmen of the 20th century and he is often regarded as one who is clever at rewriting the conversions of classical pastoral poetry and capable of the depiction of fields and farms of his surroundings and overusing the details of rural life.

In the poem Desert Places the speaker is a man who is traveling through the countryside on a beautiful winter evening. He is completely surrounded with feelings of loneliness. The speaker views a snow-covered field as a desert place. Though beautiful it is, there exists deep meditation and metaphysical truth beneath it (studentacademichelp.blogspot.com).

According to Richard Poirier (Richard Poinrier, 2000, p.147), Desert Places contains the threat for the poet "of disappearing without any record of his having been there". Frost's Introduction to King Jasper gives a specific implication to the threat, to the fear in his poem. That introduction describes as salutary "the fear of Man-the fear that men won't understand us and we shall be cut off from them." Such an existence would be a lonely, desert existence.

Over the years, there is a wide discrepancy between what life had done to Frost and what he had made out of life. Although a man stricken numerous times by pains and sufferings, he had made the most excellent works in his lifetime. The most essential thing for either appreciation or study of Frost's poetry is to have a good observation of the poet's view toward life. With this thesis, the author attempts to show a different side of Frost in a more specific and detailed way, and hopes it can help Frost readers understand him and read his poetry from a new angle.

\section{ELEMENTS' ANALYSIS}

\section{A. Theme}

The poem Desert Places was published in 1936. The poem follows a rhyming scheme of "aaba" over four stanzas, for a total of 16 lines. The poem explores the concepts of loneliness and the tie between man and nature from the first-person perspective (www.baidu.com).

It opens with the main character passing an empty field during a snowy evening. The field is surrounded by woods. He sees "loneliness" in the field where a few "weeds and stubble" peak out from the layer of snow on the ground. The animals are deep in their lairs. A picture of the nature scene has been thoroughly described (www.baidu.com).

The poet finds a truth by a lonely, suffering and desperate process, that is, the universe is without prior inherent meaning. Man is not tied to a dead universe whose overarching principle is death and separateness. Rather he finds a universe that he can fill up and fill out meaning from his own life (www.english.uiuc.edu). The experience he observes in the field literally pulls him out of himself and makes him so vulnerable to the apparent deadness that he is nearly smothered in the rarified atmosphere of loneliness and homelessness. But the poem then restores him to himself, equips him with a sense of who and where he is, and defines positively in relation to nature and to the objects to which he will give meaning poetically (www.english.uiuc.edu).

This poem is tightly controlled, terse, and deep. The theme covered here is similar to that of Dickson's poem in which she says "the brain has corridors surpassing/Material place." We needn't look very far outward: we have 
terrifying realms within. The landscape and the attendant loneliness Frost describes is the sort of thing that many Romantic poets have done, which is to project their feelings onto nature, though perhaps at the time they were writing their poems there was no distinguishing outer from inner (www.poemhunter.com).

\section{B. Title}

The title itself is a metaphor. It originally refers to the abandon places with few people there; while here it means the infinite desert within the human mind or clearly to say the moral and spiritual wilderness within the human mind. The speaker wanders who he is and where he is. Is he a part of the society or the universe or anything else? He meditates and seeks the answer in the tangible desert place. At first sight of the title, especially on seeing the word "desert", I was obsessed with a strong emotion of loneliness and could not help imaging the endless and inanimate desert without any traces of human life, no water, no plants, no animals and no human. Only the speaker himself is left there alone and keeps going and going to pursue an unknown answer...

\section{Setting}

- Time: one snowy winter night. Winter is a kind of season that can easily make men sensitive, especially the snowy winter. It is much easier to remind man's recollection to loneliness, emptiness and coldness.

- Place: a field, a desert place. The desert place with the blank landscape reinforces the feelings of emptiness and loneliness.

\section{Imagery}

- Visual: "the ground almost covered smooth in snow", "a few weeds and stubble showing"; "all animals are smothered in their lairs" and "a blanker whiteness of benighted snow". All these visual imageries present the reader a vivid picture of the desert place: a blanker whiteness of snow, weeds and stubble and smothered animals. On facing such a picture, one is easily preoccupied with the sense of emptiness and loneliness.

- Kinesthetic (sense of movement): "snow falling and night falling fast". The movement gives the reader a vivid description of the snowy winter night. And one even can feel the coldness when the snow falls down and sense the loneliness when the night comes.

- Touch: "the ground almost covered smooth in snow". When the weather is much colder than usual time the snow can be frozen and "smooth". We can imagine how inanimate the universe is in such an extreme coldness.

\section{E. Sound Quality}

- Assonance-

snow, going, almost, snow and showing;

falling, falling, going and showing;

fast, fast, past and last;

around and count;

lonely, loneliness, lonely, snow and no;

spaces, race and places.

Almost these assonances are either long vowels or diphthongs which sounds heaviness. They can show the speaker's serious and meditative mood.

- Consonance-

field, ground, covered, around, smothered and spirited;

weeds, woods, theirs, animals, lairs, includes and unawares;

spaces, stars, stars, is and places;

loneliness, less, whiteness and express.

The sound [d] sounds to haste the speaker to find the unknown answers as soon as possible. And the sounds [s] and $[\mathrm{z}]$ sounds to heavy signs. Maybe it is difficult to find the truth during such a lonely and desperate journey, so the speaker could not help sighing again and again in response to the hastiness.

- Alliteration-

falling, falling, fast, fast and field; The sound [f] alliterated five times within thirteen syllables. The reader is easy to notice such an alliterative cluster. It likes a cold air that steals across one's face. Here again emphasize the coldness of the weather and reminds us the blankness of the universe and loneliness of the speaker.

smooth, snow and stubble;

lonely, loneliness, lonely and less;

expression and express;

scare, spaces, stars, stars, so and scare. Also the cluster of the sound [s] stresses again on the lonely and desperate mood of the speaker by connecting this sound with a series of signs.

- Euphony( long vowels; liquid consonants: 1 \& r; semi - vowels: w \& y; avoidance of adjacent stresses) fast, fast, past and last in the first stanza;

snow, oh, going, almost, snow and showing in the first stanza;

lonely, loneliness, lonely and less in the third stanza. 
All these euphony make the whole poem sounds musical and harmonious.

- Cacophony-

falling, falling, fast, fast and field in the first stanza;

field, ground, covered, around, smothered and spirited in the first and second stanza;

smooth, snow and stubble in the first stanza;

scare, spaces, stars, stars, so and scare in the fourth stanza.

It is observed that in this poem euphony and cacophony are always juxtaposed. It can be understood as the foreshadowing and the consistent reminder of the conflicts between man and nature or the universe that are what discussed in the poem.

\section{F. Syntax}

- Omission: "in a field I looked into going past". The relative pronoun "that" is omitted from this line. Compare this with "in a field that I looked into going past" and you can hear how the inclusion of an extra syllable breaks the slippage toward panic in the line as we have it (www.english.uiuc.edu).

\section{G. Rhythm (Meter)}

The rhythm in this poem is irregular. Such irregular rhythm helps to achieve natural speech rhythms and makes the whole poem sound like the speech of a good storyteller. This is the favorite technique that Frost uses. It can show the process of penetration into the truth from the common phenomenon. However, there are some points worthy of our attention in this poem.

The tilt of the sound is unmistakable from the beginning (www.english.uiuc.edu). "Snow falling and night falling fast, oh, fast, In a field I looked into going past..." This meter is full of the hurry and slant of driven snow, its unstoppable, anxiety-inducing forward rush, all that whispering turmoil of a blizzard (www.english.uiuc.edu). The speaker is eager and anxiety to find the truth. Then, the end stopping of the first eight lines also contributed a tensed-up, pent-up movement. And where does that line about being "too absent-spirited to count" arrive? Does it mean that the speaker does not matter? Or something else? To count what? The animals? The lairs? And what is "it" that the woods have (www.english.uiuc.edu)? Is it loneliness? The speaker is so hypnotized by the snow swirl that he does not count as consciousness anymore; he is adrift instead in the dream of smothered lairs. And those triple masculine rhymes of "fast" "past" "last" with their monosyllabic stress repeated again in "theirs" "lairs" "awares" are like the slowing of the heartbeat in the withdrawn hibernators (www.english.uiuc.edu).

Halfway through the poem, the narcotic aspect of the snowfall is predominant, and the vowel music is like a ducked pulse beat: going, covered smooth, stubble showing, smothered. But in the next eight lines we go through the nature barrier (www.english.uiuc.edu). The consolations of being "too absent-spirited to count" are disallowed and the poem suddenly blinks itself out of reverie into vision. The vowels divest themselves of their comfortable roundness, the rhymes go slender first and then go feminine:" loneliness" "less" "express" "spaces" "race is" "places". The repetition, which at the start was conductive to trance and included speaker and reader "unawares", now buzzes everybody and everything awakes (International Edition: 1829). Again, there is a disconsolateness in the way the word" lonely" keeps rebounding off its image in the word "loneliness"; and the same holds true for the closed-circuit energy if "expression" and "express". Finally there is the repetition of the word "stars". So, by such feats of mimesis and orchestration, the speaker's inwardness with all this outward blankness is established ling before he declared himself explicitly in the concluding lines (www.english.uiuc.edu).

\section{H. Figures of Speech}

- Metaphor-

(1) Desert places. It is the man's moral and spiritual wildernesses.

(2) Field. It represents nature. At first the poet sees something with appositive existence, something he can put a name to - a field. He knows it is a field because positive signs of its identity remain: the "few weeds and stubble shoeing last". It is important to understand that this is a cultivated field and not a natural clearing in the forest (www.english.uiuc.edu). As the snow piles on, the field becomes an inanimate dead thing, unmarked by the care of man, the very thing, which gave it its positive identity as a field. Remove the signs of man's involvement; it can only be identified negatively: it is the nothingness at the center of the encircling trees (www.english.uiuc.edu). This annihilation is figured as death. So the nature itself is nothingness without any inherent or priori meaning. Only human being has such power to entrust meaning to nature.

(3) Weed. It is the primitive thing without the trace of the man.

(4) Stubble. It is the trace of man's presence.

(5) Woods. They are people and society - the owner of the field, that is, the owner of the nothingness or the meaningless things. Anyway, they have something that belongs to them, something to feel a part of (goldenessays.com).

(6) Whiteness. It represents open and empty spaces (goldenessays.com).

(7) Snow. It is a white blanket that covers up everything living (goldenessays.com).

(8) Blanker. It represents the emptiness that the speaker feels. To him there is nothing else around except for the unfeeling snow and his lonely thoughts (essaymania.com). 
(9) Home. It is a place that man can feel safety and finds his own identity there.

- Paradox

Snow and night. The poet sees the snow and the night descending together, black and white, working together to muffle sensation and obliterate perception (www.english.uiuc.edu). Such a strong contrast between the two colors easily makes man neglect the surroundings but only to surprise for the contrast. Yet they also work against each other, paradoxically, to heighten perception. The snow works against the night, giving ghastly light whereby to see the darkness, while the fast falling darkness gives urgency to the need to see, for the opportunity will not last long (www.english.uiuc.edu).

Weeds and stubble. Like the snow and the night, the weeds and stubble set up crosscurrents of meaning. The stubble is more clearly the hint of man's presence, the aftermath of man's contact with the land, while the weeds-which can exist only in the cultivated area-remind us of nature's persistent reclamation of the artificial (www.english.uiuc.edu). What the snow smothers is the vital conflict which the juxtaposition of "weeds and stubble" suggests (Perrine: 1987).

Plurality of material existence and his isolation and loneliness. The nature is a concrete complex of many material objects: woods, weeds, animals, and stars. The paradox here is the reorganization the plurality of material existence and understanding one's own place in the universe-isolation and loneliness.

The blanker whiteness has nothing to express. Nothing actually becomes something for once in a context, which is consistently negative. The intensity of nothingness begins to lend to that nothingness an almost palpable reality. It is after all that quantity which had defined the field and defined the port; and because nothingness is thus the landmark by which realities are known, it becomes a real, and in senses a positive quality (www.english.uiuc.edu).

- Transferred epithet

Night falling. Only snow or some concrete objects can fall, here "night fall" is a transferred epithet.

Benighted snow. The word "benighted" means "unenlightened morally or intellectually". We usually say "benighted savages" not "benighted snow". So here is a transferred epithet.

- Pun

Benighted snow. "Benighted" on one hand means the fall of night and on the other hand means the spiritual ignorance.

Race. On one hand it refers to the species, the human being; and on the other hand it means competition.

- Personification

"The wood around it have it-it is theirs".

"The loneliness includes me unawares".

"They cannot scare me with their empty spaces". "They" here means the nature.

The poem personifies the barren landscape surrounding him. At the beginning of the poem the speaker is so passive and negative that he even "too absent-spirited to count". This tendency is well presented by the use of personification. It seems that man is in the shadow of the nature. However, the poet relocated himself finally. "I have it in me", by this immigrant cry he locates himself as definer and namer and puts himself positively at the center of the universe. The experience he observes in the field literally pulls him out of himself and makes him so vulnerable to the apparent deadness that he is nearly smothered in the rarified atmosphere of a loneliness and homelessness. The poem restores him to himself, equips him with a sense of who and where he is, and defined positively in relation to the nature (www.english.uiuc.edu).

- Repetition

The words "falling" "fast" "loneliness" "lonely" "snow" "no" "nothing" and "stars" repeated again and again in the poem to reinforce the point what the poet wants to show.

- Hyperbole

"They cannot scare me with their empty spaces between stars". The comparison between the interstellar spaces and his own desert places also serves to aggrandize the speaker and the importance of his personal desert (www.english.uiuc.edu).

- Understatement

"They cannot scare me". The word "scare", usually applied to children's casual distress. Here it is an understatement emphasizing the speaker's deeply experienced stoicism (www.english.uiuc.edu).

I. Diction: Choice of Words and Choice of Details.

- Choice of words-

(1) Oh. The word "oh" appears between "fast" and "fast". "Oh" sounds like being driven hastefully by certain forces and reinforces the urgency to seek the truth.

(2) Past. The word "past" hints that the speaker does not stop seeking the truth even for a moment because the fields he describes are those he is going past (www.english.uiuc.edu).

(3) "It" in line five. The word "it" is an indefinite pronoun. It originally refers to the field mentioned before, but here it appears to show the indefiniteness and nothingness of the field.

(4) Count and unawares. We cannot be sure whether "count" is being used in its active sense (to count, to tell what is happening, to reckon up woods, animals and fields) or in its passive sense (to be counted, to count to anything or 
anyone else). The following line is also enriched by its apparently careless use of "unawares", which could modify loneliness or could modify me. Again the ambiguous use of the word illustrated that very unawareness, that carelessness that causes us to associate absent-spiritedness with absent-mindedness (www.english.uiuc.edu).

(5) Ere. It is an archaic word. As we have known that Frost's language is so simple and ordinary that the common readers can understand it. But this only archaic word appears here to remind us of focusing on what the adjacent sentences want to emphasize. It emphasizes the intensification of mood. The implied rebirth in the necessary melting of the snow and the reemergence of the field as a real thing is an unassimilated lump of hope (www.english.uiuc.edu).

(6) Scare. It usually applied to children's casual distress but here stresses the speaker's deeply experienced stoicism.

(7) Race. The word "race" is an active verb while the word "is" is a static one. The two contrast words create further tensions. Grammatically the two would be awkward together, as we do not coordinate an active verb with static one. Semantically the difference is related to two conflicting needs: going, doing, rushing to compete and simply being (www.english.uiuc.edu).

\section{J. Choice of Details}

- Snow and night. Snow and night represents respectively whiteness and blackness. This choice can help form a very strong contrast to show the loneliness and emptiness. A black and white contrast is created by the vision of the snow-covered field and the night (www.helium.com). The snow works against the night, giving ghastly light whereby to see the darkness, while the fast falling darkness gives urgency to the need to see, for the opportunity will not last long.

- Weeds and stubble. They also can set up crosscurrents of meaning. I have discussed it before. It is important to understand, then, that this is a cultivated field and not a natural clearing in the forest; it is nature given purpose and identity by man. Like the snow and the night, the weeds and stubble set up crosscurrents of meaning. The stubble is more clearly the hint of man's presence (www.english.uiuc.edu), of man's contact with the land, while the weeds-which can exist only in a cultivated area-remind us of nature's persistent reclamation of the artificial (goldenessays.com).

- The use of plurality. The words weed, wood, animal, stars are all used their plural forms to show the plurality of the material universe. Thus it emphasizes the loneliness of man.

- The use of personification and "I have it in me". This shows the process of man from negativeness to positiveness, from passiveness to activeness. The poet realizes finally that what he terrifies is not the nothingness of the nature but the nothingness and separateness of inner self.

\section{CONCLUSION}

The entire poem is an objective correlative for the last line. The "desert places" are within and without, and Frost conveys this by both image and the sound of his lines (www.poemhunter.com).

In the first verse snow and night fall together; in the second all life is obliterated and the third sums up the aspects of nature that include the poet as an observer. The last verse refers to Pascal's famous aphorism; the silence of these infinite spaces terrifies me. Because of Frost's superb preceding lines, it carries total conviction (www.poemhunter.com).

From these analyses, we can find that the poet finally recognizes this desert place is like his life. He had let depression and loneliness creep into his life and totally takes over like the snow had crept up on the plain and silently covered it (studentacademichelp.blogspot.com). If he does not want to live in the world meaninglessly like the nature, he should not have shut himself off to the world and let such feelings as loneliness, nothingness and coldness...run his life.

\section{APPENDIX A}

Sow falling and night falling fast, oh, fast

In a field I looked into going past,

And the ground almost covered smooth in snow,

But a few weeds and stubble showing last.

The woods around it have it - it is theirs.

All animals are smothered in their lairs.

I am too absent-spirited to count;

The loneliness includes me unawares.

And lonely as it is, that loneliness

Will be more lonely ere it will be less-

A blanker whiteness of benighted snow.

With no expression, nothing to express.

They cannot scare me with their empty spaces 
Between stars - on stars where no human race is.

I have it in me so much nearer home

To scare myself with my own desert places.

Desert Places (Robert Frost: 1936)

\section{REFERENCES}

[1] Cathy Research. Contemporary Literary Criticism. Gale research Inc.

[2] International Edition. (1829). Encyclopedia Americana. Grolier Incorporated.

[3] Laurence Perrine. (1987). Sound and Sense. Southern Methodist University.

[4] Chris Baldick. (1990). Oxford Concise Dictionary of Literary Terms. New York: Oxford University Press.

[5] AS Hornby. (1989). Oxford Advanced Learner's English-Chinese Dictionary. New York: Oxford University Press.

[6] Huang, Zongying. (2000). A Road Less Traveled By. On the Deceptive Simplicity in the Poetry of Rovert Frost. Beijing: Peking University Press.

[7] Manorama, Trikha. (1990). Robert Frost: An Anthology of Recent Criticism. New Delihi: Ace Publications.

[8] Huang, Zongying. (2000). A Road Less Traveled By. On the Deceptive Simplicity in the Poetry of Robert Frost. Beijing: Peking University Press.

[9] Parinini, Jay. (1999). Robert Frost: A Life. New York: Henry Holt and Company.

[10] www.english.uiuc.edu.

[11] www.poemhunter.com.

[12] www.helium.com.

[13] goldenessays.com.

[14] essaymania.com

[15] studentacademichelp.blogspot.com

[16] essaymania.com.

[17] Seamus Heaney. "Above the Brim.", Bloom's Modern Critical Views: Robert Frost, 20030101.

Li Wang was born in Zibo, China in 1980. She received her M.A. degree in literature from Sichuan International Studies University, China in 2006.

She is currently a lecturer in the School of Foreign Languages, Qingdao University of Science and Technology, Qingdao, China. Her research interests include British and American literature.

Ms. Wang is a member of the Research Institute of Foreign Language Literature, Qingdao University of Science and Technology. 